\title{
Highlight report: reporter cell lines for prediction of skin sensitization
}

\author{
Klaus Golka ${ }^{1}$
}

Published online: 23 November 2015

(C) Springer-Verlag Berlin Heidelberg 2015

Recently, Andreas Natsch and Roger Emter have contributed a comprehensive review article about reporter cell lines for skin sensitization testing (Natsch and Emter 2015). In the past years, several studies addressed the response of cell lines and also primary cells to skin sensitizers at the transcription level. Although the sets of up- and down-regulated genes were divergent, nevertheless three commonly found responses were identified, namely the Keap1-Nrf2ARE pathway, the heat shock response, and cytokine/ inflammatory genes (Natsch and Emter 2015). Therefore, it is apparent to establish reporter cell lines that indicate activation of these pathways. In their review, Natsch and Emter (2015) summarize the presently available cell systems and discuss their possibilities and limitations.

Currently, skin toxicology represents a cutting-edge topic (Pastore et al. 2014a, b; Takeda et al. 2014; Berthet et al. 2014; Schwarz et al. 2013; van der Veen et al. 2013) and a relatively high number of studies have focused on the metabolic capacity of skin in vitro systems (Oesch et al. 2014; Eilstein et al. 2014; Fabian et al. 2013; Esser and Götz 2013). The present intensive research activities on skin models are part of a larger development that aims at establishing alternatives to animal tests, particularly in the fields of neurotoxicity (Shinde et al. 2015; Meganathan et al. 2015; Weng et al. 2014; Krug et al. 2013; Waldmann et al. 2014) and liver toxicity (Godoy et al. 2009, 2013, 2015; Drasdo et al. 2014a, b; Hoehme et al. 2010; Schliess et al. 2014; Grinberg et al. 2014; Reif 2014). However,

Klaus Golka

golka@ifado.de

1 Leibniz Research Centre for Working Environment and Human Factors at TU Dortmund IfADo, Ardeystr. 67, 44139 Dortmund, Germany the possibilities and limitations of the currently available in vitro systems have also been critically discussed (Ghallab 2013, 2014a, b; Godoy 2011). One limitation is the inaccuracy in predicting lowest observed effect concentrations in vivo. Also, Natsch and Emter critically discuss that in vitro systems including reporter assays represent surrogate measurements whose relationship to adverse outcomes in vivo still needs to be better defined (Natsch and Emter 2015). The review is highly recommended to anyone working in the field of alternative methods.

\section{References}

Berthet A, Hopf NB, Miles A, Spring P, Charrière N, Garrigou A, Baldi I, Vernez D (2014) Human skin in vitro permeation of bentazon and isoproturon formulations with or without protective clothing suit. Arch Toxicol 88(1):77-88. doi:10.1007/ s00204-013-1087-4

Drasdo D, Bode J, Dahmen U, Dirsch O, Dooley S, Gebhardt R, Ghallab A, Godoy P, Häussinger D, Hammad S, Hoehme S, Holzhütter HG, Klingmüller U, Kuepfer L, Timmer J, Zerial M, Hengstler JG (2014a) The virtual liver: state of the art and future perspectives. Arch Toxicol 88(12):2071-2075. doi:10.1007/ s00204-014-1384-6

Drasdo D, Hoehme S, Hengstler JG (2014b) How predictive quantitative modelling of tissue organisation can inform liver disease pathogenesis. J Hepatol 61(4):951-956. doi:10.1016/j. jhep.2014.06.013

Eilstein J, Léreaux G, Budimir N, Hussler G, Wilkinson S, Duché D (2014) Comparison of xenobiotic metabolizing enzyme activities in ex vivo human skin and reconstructed human skin models from SkinEthic. Arch Toxicol 88(9):1681-1694

Esser C, Götz C (2013) Filling the gaps: need for research on cellspecific xenobiotic metabolism in the skin. Arch Toxicol 87(10):1873-1875. doi:10.1007/s00204-013-1031-7

Fabian E, Vogel D, Blatz V, Ramirez T, Kolle S, Eltze T, van Ravenzwaay B, Oesch F, Landsiedel R (2013) Xenobiotic metabolizing enzyme activities in cells used for testing skin sensitization in vitro. Arch Toxicol 87(9):1683-1696 
Ghallab A (2013) In vitro test systems and their limitations. EXCLI J 12:1024-1026

Ghallab A (2014a) Human non-parenchymal liver cells for co-cultivation systems. EXCLI J 13:1295-1296

Ghallab A (2014b) The rediscovery of HepG2 cells for prediction of drug induced liver injury (DILI). EXCLI J 13:1286-1288

Godoy P (2011) Hepatotoxicity. EXCLI J 10:124-127

Godoy P, Hengstler JG, Ilkavets I, Meyer C, Bachmann A, Müller A, Tuschl G, Mueller SO, Dooley S (2009) Extracellular matrix modulates sensitivity of hepatocytes to fibroblastoid dedifferentiation and transforming growth factor beta-induced apoptosis. Hepatology 49(6):2031-2043. doi:10.1002/hep.22880

Godoy P, Hewitt NJ, Albrecht U et al (2013) Recent advances in 2D and $3 \mathrm{D}$ in vitro systems using primary hepatocytes, alternative hepatocyte sources and non-parenchymal liver cells and their use in investigating mechanisms of hepatotoxicity, cell signaling and ADME. Arch Toxicol 87(8):1315-1530. doi:10.1007/s00204013-1078-5 (Review)

Godoy P, Schmidt-Heck W, Natarajan K et al (2015) Gene networks and transcription factor motifs defining the differentiation of stem cells into hepatocyte-like cells. J Hepatol 63(4):934-942. doi:10.1016/j.jhep.2015.05.013

Grinberg M, Stöber RM, Edlund K et al (2014) Toxicogenomics directory of chemically exposed human hepatocytes. Arch Toxicol 88(12):2261-2287. doi:10.1007/s00204-014-1400-x

Hoehme S, Brulport M, Bauer A, Bedawy E, Schormann W, Hermes M, Puppe V, Gebhardt R, Zellmer S, Schwarz M, Bockamp E, Timmel T, Hengstler JG, Drasdo D (2010) Prediction and validation of cell alignment along microvessels as order principle to restore tissue architecture in liver regeneration. Proc Natl Acad Sci U S A 107(23):10371-10376. doi:10.1073/pnas.0909374107

Krug AK, Kolde R, Gaspar JA et al (2013) Human embryonic stem cell-derived test systems for developmental neurotoxicity: a transcriptomics approach. Arch Toxicol 87(1):123-143. doi:10.1007/ s00204-012-0967-3

Meganathan K, Jagtap S, Srinivasan SP, Wagh V, Hescheler J, Hengstler J, Leist M, Sachinidis A (2015) Neuronal developmental gene and miRNA signatures induced by histone deacetylase inhibitors in human embryonic stem cells. Cell Death Dis 6:e1756. doi:10.1038/cddis.2015.121

Natsch A, Emter R (2015) Reporter cell lines for skin sensitization testing. Arch Toxicol 89:1645-1668. doi:10.1007/ s00204-015-1555-0

Oesch F, Fabian E, Guth K, Landsiedel R (2014) Xenobiotic-metabolizing enzymes in the skin of rat, mouse, pig, guinea pig, man, and in human skin models. Arch Toxicol 88(12):2135-2190. doi:10.1007/s00204-014-1382-8 (Review)
Pastore S, Lulli D, Girolomoni G et al (2014a) Replica to K. Takeda Commentary to Pastore et al. (2014): epidermal growth factor receptor signalling in keratinocyte biology: implications for skin toxicity of tyrosine kinase inhibitors. Arch Toxicol 88(12):23212322. doi:10.1007/s00204-014-1399-z

Pastore S, Lulli D, Girolomoni G (2014b) Epidermal growth factor receptor signalling in keratinocyte biology: implications for skin toxicity of tyrosine kinase inhibitors. Arch Toxicol 88(6):1189 1203. doi:10.1007/s00204-014-1244-4 (Review)

Reif R (2014) The body-on-a-chip concept: possibilities and limitations. EXCLI J 13:1283-1285

Schliess F, Hoehme S, Henkel SG, Ghallab A, Driesch D, Böttger J, Guthke R, Pfaff M, Hengstler JG, Gebhardt R, Häussinger D, Drasdo D, Zellmer S (2014) Integrated metabolic spatial-temporal model for the prediction of ammonia detoxification during liver damage and regeneration. Hepatology 60(6):2040-2051. doi:10.1002/hep.27136

Schwarz M, Münzel PA, Braeuning A (2013) Non-melanoma skin cancer in mouse and man. Arch Toxicol 87(5):783-798. doi:10.1007/s00204-012-0998-9 (Review)

Shinde V, Klima S, Sureshkumar PS, Meganathan K, Jagtap S, Rempel E, Rahnenführer J, Hengstler JG, Waldmann T, Hescheler J, Leist M, Sachinidis A (2015) Human pluripotent stem cell based developmental toxicity assays for chemical safety screening and systems biology data generation. J Vis Exp 100:e52333. doi: $10.3791 / 52333$

Takeda K, Kawamoto Y, Iida M, Omata Y, Zou C, Kato M et al (2014) Commentary to Pastore et al. (2014): epidermal growth factor receptor signaling in keratinocyte biology: implications for skin toxicity of tyrosine kinase inhibitors. Arch Toxicol 88(12):2319 2320. doi:10.1007/s00204-014-1373-9

van der Veen JW, Gremmer ER, Vermeulen JP, van Loveren H, Ezendam J (2013) Induction of skin sensitization is augmented in Nrf2-deficient mice. Arch Toxicol 87(4):763-766. doi:10.1007/ s00204-012-0976-2

Waldmann T, Rempel E, Balmer NV, König A, Kolde R, Gaspar JA, Henry M, Hescheler J, Sachinidis A, Rahnenführer J, Hengstler JG, Leist M (2014) Design principles of concentration-dependent transcriptome deviations in drug-exposed differentiating stem cells. Chem Res Toxicol 27(3):408-420. doi:10.1021/tx400402j

Weng MK, Natarajan K, Scholz D, Ivanova VN, Sachinidis A, Hengstler JG, Waldmann T (2014) Leist M (2014) Lineage-specific regulation of epigenetic modifier genes in human liver and brain. PLoS ONE 9(7):e102035. doi:10.1371/journal.pone.0102035 (eCollection) 